
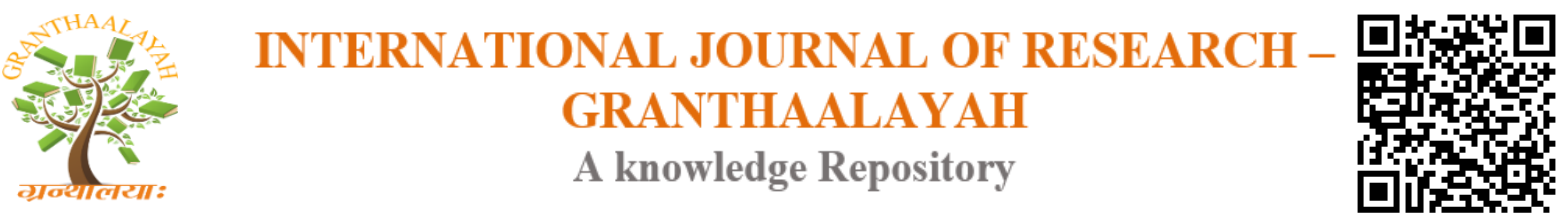

Science

\title{
ANTINATAL DIETARY CARE - A REVIEW ARTICLE
}

\author{
Dr. Ankita Rajendra Jain ${ }^{* 1}$, Dr. Vishala S. T. *2 \\ ${ }^{* 1}$ M.S. (Scholar) Streerog \& Prasutitantra, Yashwant Ayurvedic College P.G.T. \& R.C., Kodoli, \\ Kolhapur, India \\ ${ }^{* 2} \mathrm{PhD}(\mathrm{Ayu})$ Professor \& HOD of Streerog \& Prasutitantra, Yashwant Ayurvedic College \\ P.G.T. \& R.C., Kodoli, Kolhapur, India
}

\begin{abstract}
As per Ayurvedic literature each month of pregnancy has its unique requirement which is very important for every pregnant woman. There is detail description regarding pathya-apathya for garbhini.

The pregnancy diet ideally should be light, nutritious, easily digestable and rich in proteins, minerals, and vitamins. Selection of right kind of pregnancy diet can decide the mental and physical health of child so it becomes important to pay extra attention for what $u$ should eat and what $\mathrm{u}$ should not. Diet guidelines described under garbhiniparicharya is ideal protocol for pregnant women.
\end{abstract}

Keywords: Pregnancy; Monthly Diet; Healthy Fetal Growth; Maternal Health.

Cite This Article: Dr. Ankita Rajendra Jain, and Dr. Vishala S. T.. (2017). "ANTINATAL DIETARY CARE - A REVIEW ARTICLE." International Journal of Research Granthaalayah, 5(8), 202-206. https://doi.org/10.29121/granthaalayah.v5.i8.2017.2214.

\section{Introduction}

Pregnancy and childbirth have great significance in the life of each and every woman. As per Ayurvedic literature each month of pregnancy has its unique requirement which is very important for every pregnant woman.

What women eat during pregnancy is her baby's main source of nourishment. A woman who is in good stage of nourishment and therefore has enough reserve of nutrients will be able to meet the demands for nutrients of the baby growing within her.

A good nutritional level also minimise the risk of childbirth and ensure the healthy baby. The diet during pregnancy should be adequate to provide

1) Good maternal health

2) Optimum foetal growth 
3) The strength and vitality required during labour

4) Successful lactation

Malnutrition in pregnancy is a big problem in tropical countries. Any attempt to restrict the intake of food leads to nutritional deficiencies in both mother and foetus. Studies are showing that all the cell division in the brain normally occurs during gestation and in the first few months. So pregnant woman should be advised to take complete planned nutritious diet.

\section{Monthwise Regime during Pregnancy $(1,2,3,4,5,6)$}

Ayurveda recommends few things in diet corresponding to month of pregnancy responsible for healthier development of foetus.

\section{$1^{\text {st MONTH: }}$}

- Pregnant women should consume medicated or non-medicated sweet milk at least twice daily.

- Khajoora, Draksha, Manooka, Vidari, Shaliparni herb can be taken along with milk.

- For first 12 days she should taken ghrita extracted from milk. Preparation should be made in vessels of gold and silver.

\section{$2^{\text {nd }}$ MONTH:}

- Milk medicated with sweet herbs like Shatavari, Kakoli.

- Use of sweet, cold and liquid diet avoid dehydration cause by vomiting and maintain the proper health.

\section{$3^{\text {rd MONTH: }}$}

- The third month regime explains that add honey and --ghrita in milk. Honey and ghrita should be in unequal quantity.

- Use of shashti rice along with milk is recommended.

\section{$4^{\text {th }}$ MONTH:}

- $4^{\text {th }}$ month regimen recommends cooked shashti rice with curd.

- Navaneeta alone or along with milk.

\section{$5^{\text {th }}$ MONTH:}

- Ghrita only

- Yavagu( rice gruel)

- Payasa( rice cooked with milk and sweetened)

- Cooked shashti rice with milk

- Meat of wild animals

\section{$6^{\text {th }}$ MONTH:}

- Ghrita medicated with madhura-aushadhi's.

- Sweetened curd.

- Ghrita or rice gruel medicated with gokshura. 


\section{$7^{\text {th }}$ MONTH:}

- Ghrita medicated with Prithakparnyadi / Vidarigandhadi group of drugs.

- Ghrutkhanda (A sweet dish is recommended).

\section{$8^{\text {th }}$ MONTH:}

- Liquid diet prepared with ghrita.

- Rice gruel prepared with milk and mixed with ghrita should be given.

\section{$9^{\text {th }}$ MONTH:}

- Meat soup with cooked rice and ghrita.

- Rice gruel mixed with good quantity of fat.

\section{According to kashyapa: $(7,10)$}

Kashyapa says that what so ever eatables or drinkables are consumed by the pregnant women, same became congenial to the fetus, thus diet should be taken considering place of living, time or season and digestive capacity, it should never be neglected.

\section{Benefits of Following Monthly Regimen (10)}

During $1^{\text {st }}$ trimester of pregnancy most women experience nausea and vomiting, thus cannot take proper diet. Use of cold and sweet liquid diet and milk will prevent dehydration and supply required nourishment, besides the drugs of madhura group being anabolic will help to maintain proper health of mother and fetus too. $4^{\text {th }}$ month onwards muscular tissue of fetus grow sufficiently requiring more protein which is supplied by use of meat soup. By the end of $2^{\text {nd }}$ trimester women suffer from oedema of feet and other complications of water accumulation. Use of gokshura, good diuretic in six month will prevent water retention and its complications. The druds of vidarigandhadi group are diuretic, anabolic, relive emaciation and supresses kapha and pitta, their regular use in $7^{\text {th }}$ month might help in maintaining health of mother and fetus. Most women experience constipations during late pregnancy due to pressure of gravid uterus over bowels and effect of progesterone, hence use of liquid diet and grhita is recommended.

\section{According To Modern Science}

During pregnancy there is increased caloric requirement due to increased growth of maternal tissue, foetus, placenta, and increased basal metabolic rate.

According to ACOG Pregnant women needs more calcium, folic acid, iron and proteins, vitamins than a women who is not expecting.

\section{Nutrients that is important in Pregnancy (9)}

\section{1) FOLIC ACID (400 $\mu$ g daily)}

Folic acid and vitamin B12 are specially required for for cell division and development of foetal nervous system. Inadequacy of folic acid can leads to neural tube defect hence it is recommended as prenatal supplement. Sources of folic acid from diet are spinach, almonds, orange, broccoli, strawberry, papaya, beans, asparagus, beet mushroom etc. 


\section{2) PROTIEN (60 gms daily)}

Protein is builder nutrient. Development of baby needs plenty of proteins specially during $2^{\text {nd }}$ and $3^{\text {rd }}$ trimester. Pregnant women advised to consume 4 servings of protein food daily in addition to their 4 servings of milk. Seafood, eggs, beans, soya, milk, yogurt, sprouts, cereals etc. are the sources of protein.

\section{3) IRON (40 mg daily)}

Both foetus and mother needs iron to make red blood cells. Getting too little iron can cause fatigue and increased chances of infection. It is almost impossible to obtain iron required during pregnancy from food alone, iron supplement is recommended. Red meat, dried fruits, beans, dark green leafy vegetables, jaggery, whole wheat breads are the sources of iron.

\section{4) CALCIUM (1000mg daily)}

Calcium is needed for growth of bones and teeth of baby. If dietary calcium is insufficient, calcium will be released from mother's bone that's why woman is advised to consume four servings of milk and dairy products during pregnancy. Milk, broccoli, cheese, yogurt, fortified tofu, fish, ragi possesses good quantity of calcium.

Generally diet in pregnancy should be with women's choice as regard the quantity and type. Women with normal BMI should eat adequately so as to gain optimum weight $(11 \mathrm{~kg})$. overweight women with BMI between $26-29$ should limit weight gain to $7 \mathrm{~kg}$ and obese women $($ BMI > 29) should gain less weight. Excessive gain in weight can lead to antepartum and intrapartum complications including fetal macrosomia.

Dietetic advise should be given with due consideration to the socio-economic condition, food habits and taste of the individual. (9)

\section{Discussion}

To have a healthy baby it's important to follow month wise regime prescribed by Acharya. Diet should be easily digestable, nutritious, rich in various nutrients like proteins, vitamins, minerals etc. The goal is to eat nutritious food most of the time. Most important advice is to eat what pregnant women naturally desire. Gratifying her desire will result in strong, long live, virtuous child.

Use of month wise regime makes her sacral region, flanks and back soft. Vayu moves into its right path. Faeces, urine and placenta are expelled easily. Women gains strength, complexion and delivers easily at a proper time a desire, excellent, healthy child possessing all the qualities and long life.

\section{Conclusion}

Pregnancy is stage of rapid growth of fetus in mother body. Her body itself changes Physiologically to help growth of fetus and preparation of laction. Nutrition is the key component in the antenatal care of women. Thus, sufficient nutrients from diet and proper health care should maintained for safe delivery. 


\section{References}

[1] Charak smahita sharir stan 8/32, by vd. Ya. Go. Joshi. Vaidyamitra prakashana, 4th edition, 2009, page no 743 to 744 .

[2] Sushrut samhita sharir sthana $10 / 4$, by Acharya priyawat sharma translated by vd.anantaram sharma chaukhamba prakashana, Varanasi, volume 2, 2010, page no.127.

[3] Ashtanga sangraha sharir sthana 3/3-13, by dr. jyotirmitra acharyakrut Sanskrit angreji upodhat sahit,chaukhamba publication Varanasi, edited by suprasad sharma, third edition, 2012, page no 285 to 286.

[4] Ashtanga hridayam sharirsthan $1 / 64-65$, translated by k. r. srhikantha murthy, chaukhamba krishnadas academy, 7th edition 2010. Page no 372.

[5] Harit samhita tritiya sthana 49/1-2, Sanskrit mul va nirmala hindi tika, sampaak avum anuvadak vd. Jaymini pandey. Published by chaukhamba vishvabharati, page no 452-453.

[6] Bhela samhita sharir sthana 8, text with English translation by dr. k.h. Krishna murthy, chaukhamba vishvabharati 2008, page no 240 to 244.

[7] Kashyapa samhita khilasthana24/6,7,11,12 text eith English translation and commentary, edited by prof. p. v. Tiwari with dr. neeraj kumar, Dr. R. D. sharma and Dr. Abhimanyu kumar.

[8] Nutrition and diet therapy, sheel sharma, peepee publication,chapter no 15, page no 156 to 158.

[9] D.C. Datta obst, harilal konar,jaypee publication, 7th edition, chapter no10, page no 99 to 100.

[10] Ayurvediya Prasutitantra evum streeroga,part 1, prasutitantra,prof.km.Premvati Tiwari, Chaukhamba orientalia, chapter no 5, page no 218 to 228.

*Corresponding author.

E-mail address: anki.freesoul@ gmail.com/ vishalaturlapati@gmail.com 